\title{
PELAPORAN KEWAJIBAN PERPAJAKAN DILIHAT DARI TINGKAT PEMAHAMAN, KEPATUHAN, DAN KETEGASAN SANKSI PERPAJAKAN PEMILIK UMKM DI KOTA JAMBI
}

\section{REPORTING TAX OBLIGATION OF THE OWNER OF UMKM IN JAMBI: UNDERSTANDING LEVEL, ALLEGIANCE, AND THE FIRMNESS OF TAX SANCTION LEVEL}

\author{
Mellya Embun Baining dan Nurhasanah \\ Fakultas Ekonomi dan Bisnis Islam UIN Sultan Thaha Saifuddin Jambi \\ Jl. Arif Rahman Hakim No. 1, Telanaipura Jambi \\ e-mail: mellyaembun.baining@gmail.com
}

Naskah diterima 02 Mei 2018, di-review 01 Juni 2018, disetujui 22 Juni 2018

\begin{abstract}
This study is aimed at finding factors affecting the owner of Micro Small Medium Enterprises (SMEs) in reporting tax obligation in Jambi. The research method was quantitative research. Data were collected through questionnaire and document and analyzed quantitatively; descriptive analysis, validity and reliability tests, multi linear regression analysis, T test, $F$ Test, and coefficient of determination analysis. The research finding indicates the level of understanding, allegiance, and the firmness of tax sanction influence significantly toward reporting tax obligation. It can be seen from the result f test where $F_{\text {hitung }} 11,196>F_{\text {tabel }}$ 3,09 with 0,0000 significance level, and the determination coefficient value is 0,236. It means 23,6\% of the level of understanding, allegiance, and the firmness of tax sanction toward reporting tax obligation, while $76,4 \%$ is influenced by other factors. Specifically it can be elaborated as follows: (1) the understanding level gains $T_{\text {hitung }} 2,156$ is higher than $T_{\text {tabel }} 1,984\left(T_{\text {hitung }}>T_{\text {tabe }}\right)$, with 0,034 significance value. (2) the allegiance level gets $T_{\text {hitung }} 2,014$ is higher than $T_{\text {tabel }} 1,984\left(T_{\text {hitung }}>T_{\text {tabel }}\right)$ with 0,047 significance value, (3) the firmness of tax sanction receives $T_{\text {hitung }} 2,156$ is higher than $T_{\text {tabel }} 1,984\left(T_{\text {hitung }}>T_{\text {tabe }} l\right)$, with 0,034 significance value.
\end{abstract}

Keywords: the understanding level, allegiance level, the firmness of tax sanction level, SMEs, and tax

\begin{abstract}
Abstrak: Penelitian ini bertujuan untuk mengetahui faktor-faktor yang mempengaruhi pemilik Usaha Mikro Kecil Menengah (UMKM) dalam pelaporan kewajiban perpajakan di Kota Jambi. Metode penelitian ini adalah penelitian kuantitatif. Pengumpulan data yang dilakukan dengan menyebarkan angket (kuesioner) dan dokumentasi. Sampel dalam penelitian ini berjumlah 100 orang. Analisis data yang digunakan dalam penelitian ini yaitu analisis deskriftif, uji validitas, uji relibilitas, analisis regresi linear berganda, uji T, uji F, dan analisis koefisien determinasi. Penelitian dilakukan dengan persamaan regresi linier berganda untuk tingkat pemahaman, tingkat kepatuhan, dan ketegasan sanksi perpajakan terhadap pelaporan kewajiban perpajakan adalah $\mathrm{Y}=5,706+2,156 \mathrm{X}_{1}+2,014 \mathrm{X}_{2}$ $+2,659 X_{3}+$ e. Pengaruh tingkat pemahaman berpengaruh signifikan terhadap pelaporan kewajiban perpajakan karena $t_{\text {hitung }}>t_{\text {tabel }}$ atau 2,156 >1,984 dan nilai signifikasi 0,034<level of significant 0,05. Pengaruh tingkat kepatuhan berpengaruh signifikan terhadap pelaporan kewajiban perpajakan karena $t_{\text {hitung }}>t_{\text {tabel }}$ atau 2,014 >1,984 dan nilai signifikan 0,047 <level of significant 0,05. Ketegasan sanksi perpajakan berpengaruh signifikan terhadap pelaporan kewajiban perpajakan karena nilai $t_{\text {hitung }}>t_{\text {tabel }}$ atau 2,659 > 1,984 dan nilai signifikan 0,009 < level of significant 0,05. Pengaruh tingkat pemahaman, tingkat kepatuhan dan ketegasan sanksi perpajakan karena hasil uji F yang dilakukan menghasilkan nilai $\mathrm{F}_{\text {hitung }} 11,196>\mathrm{F}_{\text {tabel }} 3,09$ dan nilai signifikansinya 0,000 <level of significant 0,05 . Nilai koefisien determinasinya adalah 0,236 berarti besarnya pengaruh tingkat pemahaman, tingkat kepatuhan, dan ketegasan sanksi perpajakan terhadap pelaporan kewajiban perpajakan dilihat dari nilai $\mathrm{R}^{2}$ yaitu $23,6 \%$ sedangkan sisanya $76,4 \%$ dipengaruhi variabel lain.
\end{abstract}

Kata Kunci: tingkat pemahaman, tingkat kepatuhan, ketegasan sanksi perpajakan, UMKM, dan pajak 


\section{PENDAHULUAN}

$S$ ektor Usaha Mikro, Kecil, Menengah (UMKM) merupakan komponen penting bagi upaya pemberdayaan ekonomi rakyat. Ini terbukti bahwa sektor UMKM secara potensial mempunyai modal sosial untuk berkembang wajar dan bertahan pada semua kondisi dan relatif mandiri karena tidak tergantung pada dinamika sektor moneter secara nasional. Sektor UMKM juga mempunyai potensi yang besar menyerap tenaga kerja, penyumbang devisa, penghasil berbagai barang murah, dan terjangkau oleh kekuatan ekonomi rakyat dan distribusinya menyebar luas. (Sukirno, 1991: 71).
Hal ini juga bersumber dari keterbelakangan yang merupakan ciri pokok negara berkembang termasuk Indonesia. Untuk menciptakan kondisi ini, salah satu terobosan yang dilakukan pemerintah adalah mendorong, membina, dan mengembangkan potensi UMKM. Salah satunya meningkatkan pertumbuhan UMKM atau mengembangkan pertumbuhan UMKM, baik yang merupakan indikator dalam perkembangan UMKM diantaranya yaitu modal, omset, banyaknya jumlah usaha, tenaga kerja, dan aset. Berikut merupakan perkembangan UMKM di kota Jambi tahun 2014-2016.

Tabel 1

Perkembangan UMKM di Kota Jambi tahun 2014-2016

\begin{tabular}{|l|l|r|r|r|r|r|r|}
\hline \multirow{2}{*}{ No } & \multirow{2}{*}{ Kriteria UMKM } & \multicolumn{2}{|l|}{ Tahun } & \multicolumn{2}{l|}{ Presentase (\%) Pertumbuhan UMKM } \\
\cline { 2 - 7 } & & 2014 & 2015 & 2016 & 2014 & 2015 & 2016 \\
\hline 1 & Usaha Mikro & 8.157 & 8.197 & 8.708 & $-6,55$ & 0,49 & 6,23 \\
\hline 2 & Usaha Kecil & 1.763 & 1.792 & 1.800 & 48,4 & 1,64 & 0,45 \\
\hline 3 & Usaha Menengah & 354 & 354 & 360 & 230,8 & 0 & 1,69 \\
\hline & Jumlah & 10.274 & 10.343 & 10.868 & 2,49 & 0,67 & 5,07 \\
\hline
\end{tabular}

Sumber: Dinas Koperasi dan UMKM Kota Jambi

Dari data di atas dapat dilihat perkembangan UMKM dari tahun 2014-2016 terus mengalami peningkatan yaitu pada tahun 2014 sebanyak 10.274 unit, 2015 sebesar 10.343 unit dan ditahun 2016 sebesar 10.886 unit. Untuk presentase perkembangan UMKM setiap tahunnya selalu mengalami peningkatan, dan rata-rata tumbuh 300 UMKM baru per tahun. (n.d., http://www. antarajambi.com, akses 26 Januari 2017)

Perkembangan sektor UMKM yang begitu pesat memperlihatkan bahwa terdapat potensi yang besar jika hal ini dikelola dan dikembangkan dengan baikyang tentunya akan dapat mewujudkan UMKM yang tangguh. Dengan mengalami peningkatan jumlah UMKM dari tahun ke tahun, maka akan menambah pendapatan negara yaitu berupa pajak. Pembangunan di negara ini dapat berlangsung berkat kontribusi pelaku UMKM. Para pelaku UMKM menyadari bahwa pembangunan dapat berlangsung dengan baik berkat setoran pajak ke kas negara, tetapi dalam hal ini UMKM masih dihadapkan pada masalah yang terletak pada kewajiban perpajakan yang berlaku. (Budi, 2013: 1)

Oleh karena itu pemerintah pada tahun 2013 mengeluarkan PP No. 46 yang mengatur pengenaan pajak penghasilan atas usaha dengan omset 4,8 milyar dikenakan pajak sebesar $1 \%$ dikenal dengan istilah Pph untuk UMKM. Berikut merupakan data jumlah wajib pajak UMKM di Kota Jambi pada tahun 2014-2016: 
Tabel 2

Jumlah Wajib Pajak UMKM di Kota Jambi Tahun 2014-2016

\begin{tabular}{|l|r|}
\hline Tahun & Wajib Pajak \\
\hline 2014 & 3.828 \\
\hline 2015 & 5.782 \\
\hline 2016 & 6.889 \\
\hline Jumlah & 16.499 \\
\hline
\end{tabular}

Sumber: Kantor Pelayanan Pajak (KPP) Pratama Jambi

Dari data di atas dapat dilihat bahwa sektor UMKM dihadapkan pada masalah yang terletak pada kewajiban perpajakan. Data perkembangan UMKM di Kota Jambi dari tahun 2014-2016 belum terdaftar sebagai wajib pajak.

Tabel 3

Pertumbuhan Pajak UMKM

\begin{tabular}{|l|l|l|r|}
\hline Tahun & Wajib Pajak & UMKM & Presentase \\
\hline 2014 & 3.828 unit & 10.274 unit & $37,3 \%$ \\
\hline 2015 & 5.782 unit & 10.343 unit & $55,9 \%$ \\
\hline 2016 & 6.889 unit & 10.868 unit & $63,4 \%$ \\
\hline
\end{tabular}

Sumber: Kantor Pelayanan Pajak (KPP) Pratama Jambi

Dari data di atas dapat dilihat bahwa semakin bertambahnya jumlah UMKM dari tahun ke tahun, maka semakin bertambah pula UMKM yang membayar pajak, tetapi hanya sebagian belum $100 \%$.

Fenomena perpajakan merupakan pengetahuan yang tidak seragam di tengah masyarakat. Hal ini dibuktikan dengan penelitian Rajabudin Nasution membuktikan bahwa pengetahuan wajib pajak secara parsial tidak berpengaruh terhadap kesadaran kewajiban perpajakan. Namun pemahaman system self assessment berpengaruh terhadap kesadaran kewajiban perpajakan. Tingkat pendapatan wajib pajak tidak berpengaruh terhadap kesadaran kewajiban perpajakan. Sedangkan secara simultan penelitian membuktikan bahwa pengetahuan wajib pajak, pemahaman system self assessment dan tingkat pendapatan wajib pajak berpengaruh terhadap kesadaran kewajiban perpajakan pada berjumlah 31.485 unit, sedangkan UMKM yang terdaftar sebagai wajib pajak di Kota Jambi tahun 2014-2016 hanya 16.499 unit, 14.986 unit UMKM 
Rp. 779 juta, pajak hiburan Rp. 265 juta, pajak hotel sebesar Rp. 107 juta, pajak sewa tanah Rp. 3,7 juta, piutang pajak galian golongan C Rp. 17 juta serta Rp. 4,7 miliar piutang pajak yang tidak dapat ditagih lagi, dengan alasan wajib pajak usaha mereka telah tutup. Ucok Sky Khadafi mengatakan dengan tunggakan pajak yang cukup tinggi dan selalu menjadi temuan BKPRI sejak setahun terakhir, ini jelas membuktikan masih lemahnya kemampuan pengelolaan pajak di kota Jambi, padahal pajak merupakan salah satu sektor primadona PAD bagi kota Jambi yang dapat mendukung kemajuan pembangunan kota. (n.d., http://www.jpnn.com, diakses 14 Maret 2017)

Dari beberapa benturan antara teori dan temuan riset di atas menyisikan ruang kosong untuk peneliti mendalami topik permasalah dengan judul Pelaporan Kewajiban Perpajakan Dilihat dari Tingkat Pemahaman, Kepatuhan, dan Ketegasan Sanksi Perpajakan Pemilik UMKM di Kota Jambi.

Berdasarkan latar belakang masalah yang telah dipaparkan, rumusan masalah penelitian ini sebagai berikut: (1) Bagaimana pengaruh tingkat pemahaman, tingkat kepatuhan dan ketegasan sanksi perpajakan pemilik UMKM terhadap pelaporan kewajiban perpajakan di Kota Jambi? (2) Faktor apa yang paling dominan pemilikUMKM dalam pelaporan kewajiban perpajakan di Kota Jambi?

Faktor-faktor yang Mempengaruhi Pemilik UMKM dalam Pelaporan Kewajiban Perpajakan

\section{Tingkat Pemahaman}

Pemahaman wajib pajak terhadap peraturan perpajakan adalah cara wajib pajak dalam memahami peraturan perpajakan yang telah ada. Menurut Widayati beberapa indikator wajib pajak mengetahui dan memahami peraturan perpajakan. Pertama, kepemilikan NPWP. Kedua, pemahaman mengenai hak dan kewajiban sebagai wajib pajak. Ketiga, pemahaman mengenai sanksi perpajakan. Keempat, pemahaman mengenai PTKP, PKP, dan tarif pajak. Kelima, wajib pajak memahami peraturan perpajakan melalui sosialisasi yang dilakukan oleh KPP. Keenam, bahwa wajib pajak memahami peraturan pajak melalui training perpajakan yang mereka ikuti. (Priyanti, 2013: 32-33)

Berdasarkan hasil penelitian yang dilakukan oleh RM. Sayid Fiska Kusuma Wijaya dapat disimpulkan bahwa pengetahuan dan pemahaman perpajakan berpengaruh signifikan terhadap kemauan membayar pajak terlihat pada nilai $\mathrm{F}$ hitung 15,538 dengan nilai signifikansi 0,000. (Wijaya, skripsi, 2014: t.h.)

\section{Tingkat Kepatuhan}

Menurut Kriyanto kepatuhan wajib pajak adalah suatu ketaatan untuk melakukan ketentuanketentuan atau aturan-aturan perpajakan yang diwajibkan atau diharuskan untuk dilaksanakan. Berdasarkan penelitian yang dilakukan oleh I Putu Waras Wirapati dapat disimpukan bahwa variabel penghasilan WP, berpengaruh positif signifikan secara parsial terhadap variabel kepatuhan pengrajin dalam memiliki NPWP yang berarti semakin besar penghasilan WP maka dapat meningkatkan kepatuhan pengrajin dalam memiliki NPWP. WP yang memiliki penghasilan besar cenderung untuk lebih patuh dalam pelaporan 
kewajiban perpajakannya dari pada WP yang berpenghasilan lebih rendah (Wirapati, 2014: t.h.).

Kepatuhan wajib pajak tersebut diukur dengan indikator sebagai berikut:

1. Memiliki NPWP merupakan salah satu bentuk kepatuhan terhadap ketentuan perpajakan.

2. Memiliki NPWP berarti menjadi warga negara yang taat pajak.

3. Pemahaman terhadap ketentuan peraturan perpajakan (Wirapati, 2014: 298)

\section{Ketegasan Sanksi Perpajakan}

Sanksi perpajakan merupakan jaminan bahwa ketentuan peraturan perundangundangan perpajakan (norma perpajakan) akan dituruti/ditaati/dipatuhi, dengan kata lain sanksi perpajakan merupakan alat pencegah agar WP tidak melanggar norma perpajakan menurut Mardiasmo. Ketegasan sanksi perpajakan berpengaruh signifikan terhadap kewajiban perpajakan, hal ini berdasarkan penelitian yang dilakukan Harjanti Puspa Arum menunjukkan bahwa semakin tinggi tingkat pemahaman wajib pajak tentang sanksi pajak maka akan semakin tinggi pelaporan kewajiban perpajakannya (Arum, t.th.: t.h.)

Sanksi pajak tersebut diukur dengan indikator sebagai berikut:

1) Sanksi berupa tarif pemotongan pajak yang lebih tinggi.

2) Sanksi pidana penjara.

3) Sanksi denda.

4) Sanksi administrasi membuat WP memiliki NPWP. (Mardiasmo, 2011, 59)

\section{Hipotesis Penelitian}

Hipotesis adalah suatu dugaan jawaban yang paling memungkinkan walaupun masih harus dibuktikan dengan penelitian (Hariwijaya, 2009: 50-51). Berdasarkan pengertian di atas, maka hipotesis penelitian ini adalah sebagai berikut:

Ha : Tingkat pemahaman, tingkatkepatuhan, dan ketegasan sanksi perpajakan berpengaruh terhadap pelaporan kewajiban perpajakan di Kota Jambi.

Ho : Tingkat pemahaman, tingkat kepatuhan, dan ketegasan sanksi perpajakan tidak berpengaruh terhadap pelaporan kewajiban perpajakan di Kota Jambi.

\section{METODE PENELITIAN}

\section{Pendekatan Penelitian}

Pendekatan yang digunakan dalam penelitian ini adalah jenis penelitian deskriptif dengan pendekatan kuntitatif.

\section{Jenis dan Sumber data}

\section{Jenis Data}

Adapun data primer dalam penelitian ini adalah data yang penulis peroleh langsung dari sumbernya, yaitu data yang diambil dari hasil penyebaran kuisioner tentang tingkat pemahaman, tingkat kepatuhan, dan ketegasan sanksi perpajakan pemilik UMKM terhadap pelaporan kewajiban perpajakan.

Dalam penelitian ini, yang menjadi data skunder adalah data-data yang diperoleh dari buku-buku, artikel, internet, serta bahan pustaka yang diambil dari penelitian sebelumnya. 


\section{Sumber Data}

Sumber data adalah subjek dari mana data dapat diperoleh (Arikunto, 2006: 129). Sesuai dengan metode yang digunakan, maka yang menjadi sumber data dalam penelitian ini adalah hal-hal yang menyangkut UMKM dalam pelaporan kewajiban perpajakan serta data yang bersumber dari penyebaran kuisioner yang peneliti sebarkan kepada UMKM di Kota Jambi.

\section{Instrumen Pengumpulan Data}

Instrumen pengumpulan data adalah alat yang digunakan untuk mengumpulkan data dan fakta penelitian (Tim Penyusun, 2010: 25).

1. Angket (Kuesioner) adalah pengumpulan data dengan cara menggunakan daftar pertanyaan yang diajukan kepada responden untuk dijawab dengan memberikan angket (Sunyoto, 2013: 23).

2. Dokumentasi adalah teknik pengumpulan data dengan memanfaatkan data sekunder yang telah tersedia dalam perpustakaan, dari instasi yang diteliti atau dari tempat lain yang dijamin kebenarannya.

\section{Populasi dan Sampel}

Populasi pada penelitian ini adalah seluruh pemilik UMKM yang berada di Kota Jambi hingga tahun 2016 berjumlah 10.868 unit.

Adapun sampel pada penelitian ini adalah beberapa pemilik UMKM yang berada di Kota Jambi. Cara menghitung sampel ditentukan dengan rumus: (Prasetyo, 2014: 137)

$$
\mathrm{n}=\frac{N}{1+N \cdot e^{2}}
$$

\section{4| Mellya Embun Baining, Nurhasanah}

Dimana:

$$
\begin{aligned}
& \mathrm{n} \text { : Sampel } \\
& \mathrm{N} \text { : Jumlah populasi } \\
& \text { e : error (Kesalahan yang diterima) }
\end{aligned}
$$

Dengan menggunakan margin of error sebesar $10 \%$, maka jumlah sampel yang dapat diambil adalah sebagai berikut :

$$
\begin{aligned}
& \mathrm{n}=\frac{10.868}{1+10.868 \cdot 0,1^{2}} \\
& \mathrm{n}=\frac{10.868}{108,69} \\
& \mathrm{n}=99,99
\end{aligned}
$$

Dibulatkan menjadi 100

Berdasarkan hasil perhitungan di atas, maka jumlah sampel yang akan digunakan dalam penelitian ini sebanyak 100 responden.

\section{Uji Coba Statistik}

\section{Uji Validitas Instrumen}

Validitas adalah suatu ukuran yang meninjukkan tingkat keandalan suatu alat ukur. Jika instrumen dikatakan valid berarti menunjukkan alat ukur yang digunakan untuk mendapatkan data itu valid sehingga valid berarti instrumen tersebut dapat digunakan untuk mengukur apa yang seharusnya diukur.

Pengambilan keputusan bahwa setiap indikator valid apabila nilai $r$ hitung lebih besar atau sama dengan $r$ tabel atau $r$ hitung berada dibawah 0,05 (Usman, 2008: 288). Dapat pula digunakan rumus teknik korelasi product moment.

$$
\mathrm{Rxy}=\frac{\mathrm{N} \Sigma \mathrm{XY}-(\Sigma \mathrm{X})(\Sigma \mathrm{Y})}{\sqrt{\{\mathrm{N} \Sigma \mathrm{X} 2-\Sigma \mathrm{X} 2\}\{\mathrm{N} \Sigma \mathrm{Y} 2-\Sigma \mathrm{Y} 2\}}}
$$

Keterangan:

$$
\text { rxy = Koefisien korelasi product moment }
$$


$\mathrm{N}=$ Jumlah responden

$\mathrm{X}=$ Skor butir item tertentu

$\mathrm{Y}=$ Skor total

$\Sigma \mathrm{X}=$ Jumlah skor butir

$\Sigma \mathrm{Y}=$ Jumlah skor total

$\Sigma \mathrm{XY}=$ Perkalian skor butir dan skor total

$\Sigma X 2=$ Jumlah kuadrat skor butir

$\Sigma Y 2=$ Jumlah kuadrat skor total

\section{Uji Reliabilitas Instrumen}

Reliabilitas menunjukkan pada suatu pengertian bahwa suatu instrumen cukup dapat dipercaya untuk dapat digunakan sebagai alat pengumpulan data karena instrumen tersebutsudah baik. Untuk menguji reliabilitas digunakan teknik croancbach alpha $>0,06$. Dimana pada pengujian ini menggunakan bantuan program software. Rumus croancbach alpha adalah sebagai berikut:

Keterangan:

$$
\mathrm{r} 11=\left(\frac{K}{K-1}\right)\left(1-\frac{\Sigma \sigma \mathrm{b}}{\sigma 2 \mathrm{t}}\right)
$$

$$
\begin{aligned}
& \mathrm{r} 11=\text { Reliabilitas instrumen } \\
& \mathrm{k} \quad=\text { Banyaknya butir pernyataan atau } \\
& \quad \text { pertanyaan } \\
& \Sigma \sigma \mathrm{b}=\text { Jumlah varian butir } \\
& \sigma 2 \mathrm{t}=\text { Varian total }
\end{aligned}
$$

\section{Teknik Analisis Data}

\section{Uji Regresi Linear Berganda}

Analisis regresi linear berganda digunakan untuk mengetahui seberapa besar pengaruh variabel terikat (variabel dependen) dalam hal ini yaitu pelaporan kewajiban perpajakan dan tiga variabel independen yaitu tingkat pemahaman $\left(\mathrm{X}_{1}\right)$, tingkat kepatuhan $\left(\mathrm{X}_{2}\right)$, ketegasan sanksi perpajakan $\left(\mathrm{X}_{3}\right)$. Model yang dapat dibentuk sesuai dengan tujuan penelitian adalah:

$$
\mathrm{Y}=\alpha+\beta 1 \mathrm{X} 1+\beta 2 \mathrm{X} 2+\beta 3 \mathrm{X} 3+\mathrm{e}
$$

Dimana:

$$
\begin{aligned}
\mathrm{Y}= & \text { Pelaporan kewajiban perpajakan } \\
& \text { (variabel dependen) } \\
\mathrm{a}= & \text { Konstanta } \\
\beta 1= & \text { Koefisien regresi dari variabel X1 } \\
& \text { (tingkat pemahaman) } \\
\beta 2= & \text { Koefisien regresi dari variabel X2 } \\
& \text { (tingkat kepatuhan) } \\
\beta 3= & \text { Koefisien regresi dari variabel X3 } \\
& \text { (ketegasan sanksi perpajakan) } \\
X_{1}= & \text { Tingkat Pemahaman } \\
X_{2}= & \text { Tingkat Kepatuhan } \\
X_{3}= & \text { Ketegasan Sanksi Perpajakan } \\
e^{=}= & \text {Error }
\end{aligned}
$$

\section{Uji Parsial (t)}

Uji parsial bertujuan untuk mengetahui besarnya pengaruh masing-masing variabel independen secara individual (parsial) terhadap variabel dependen. Hipotesis yang digunakan adalah:

Menentukan Ho dan Ha

1. Ho diterima, Ha tolak, jika $t_{\text {hitung }}<t_{\text {tabel }}$ atau Sig $>\alpha$ (tidak terdapat pengaruh yang signifikan).

2. Ho diterima, Ha tolak, jika $t_{\text {hitung }}>t_{\text {tabel }}$ atau Sig $<\alpha$ (terdapat pengaruh yang signifikan).

\section{Uji Simultan (F)}

Secara simultan, pengujian hipotesis dilakukan dengan ujian F-test. Uji statistif $\mathrm{F}$ pada dasarnya menunjukkan apakah semua variabel bebas dimasukkan ke dalam model mempunyai pengaruh secara bersama-sama terhadap variabel terikat. Uji ini dibantu dengan 
menggunakan program software SPSS. Uji ini dilakukan dengan membandingkan signifikan $\mathrm{f}_{\text {hitung }}$ dengan ketentuan:

1. Ho diterima, Ha ditolak, jika $\mathrm{f}_{\text {hitung }}<\mathrm{f}_{\text {tabel }}$ atau Sig $>\alpha$ (tidak terdapat pengaruh yang signifikan).

2. Ho diterima, Ha ditolak, jika $\mathrm{f}_{\text {hitung }}>\mathrm{f}_{\text {tabel }}$ atau Sig $<\alpha$ (terdapat pengaruh yang signifikan.

\section{Uji Koefisien Determinasi $\left(R^{2}\right)$}

Koefisien determinasi $\left(\mathrm{R}^{2}\right)$ bertujuan mengukur seberapa jauh kemampuan model dalam menerangkan variasi variabel terikat. Dalam penelitian ini perhitungan koefisien determinasi untuk mengukur seberapa jauh kemampuan variabel-variabel bebas (Y) dalam menjelaskan variabel terikat $\left(\mathrm{X}_{1}, \mathrm{X}_{2}, \mathrm{X}_{3}\right)$.

Dengan mengetahui nilai koefisien determinasi dapat dijelaskan kebaikan dari model regresi dalam memprediksi variabel dependen. Semakin tinggi nilai koefisien determinasi akan semakin baik kemampuan variabel independen dalam menjelaskan perilaku variabel dependen. Hasil pengujian koefisien determinasi dapat dilihat dari nilai adjusted $R$ square pada analisis regresi berganda.

\section{PEMBAHASAN DAN HASIL}

Pengaruh Tingkat Pemahaman, Tingkat Kepatuhan, dan Ketegasan Sanksi Perpajakan Terhadap Pelaporan Kewajiban Perpajakan

Hasil penelitian diketahui bahwa variabel tingkat pemahaman (X1) berpengaruh positif dan signifikan terhadap pelaporan kewajiban perpajakan. Hal ini di tunjukkan oleh koefisien regresi X1 sebesar 0,117. Nilai signifikan variabel tingkat pemahaman sebesar 0,034 hal ini berarti lebih kecil dari 0,05. Nilai $t_{\text {hitung }}>t_{\text {tabel }}$ atau 2,156 $>1,984$, sehingga variabel tingkat pemahaman berpengaruh signifikan terhadap pelaporan kewajiban perpajakan. Dengan adanya pemahaman tentang perpajakan dapat mendorong pemilik UMKM untuk melaporkan kewajiban perpajakannya. Hal ini tidak sesuai dengan penelitian Choirizatuz Zahidah tahun 2010 bahwa tingkat pemahaman berpengaruh negatif signifikan terhadap kewajiban perpajakan. Dengan demikian, semakin tinggi pemahaman pengusaha UMKM terhadap peraturan perpajakan maka kesadaran dalam pelaporan kewajiban perpajakannya akan semakin rendah. Hal ini disebabkan karena para pengusaha UMKM mempunyai kesadaran yang rendah dalam hal pelaporan kewajiban perpajakannya.

Hasil penelitian diketahui bahwa variabel tingkat kepatuhan (X2) berpengaruh positif dan signifikan terhadap pelaporan kewajiban perpajakan. Hal ini di tunjukkan oleh koefisien regresi X2 sebesar 0,108. Nilai signifikan variabel tingkat pemahaman sebesar 0,047 hal ini berarti lebih kecil dari 0,05. Nilai $t_{\text {hitung }}>t_{\text {tabel }}$ atau 2,014 > 1,984 , sehingga mengindikasikan bahwa variabel tingkat kepatuhan berpengaruh signifikan terhadap pelaporan kewajiban perpajakan. Dengan demikian, pemilik UMKM menyadari suatu ketaatan untuk melakukan ketentuanketentuan atau aturan-aturan perpajakan yang diwajibkan atau diharuskan untuk dilaksanakan. Hasil penelitian ini konsisten dengan penelitian yang dilakukan Kriyanto 2010. 
Hasil penelitian diketahui bahwa variabel ketegasan sanksi perpajakan (X3) berpengaruh positif dan signifikan terhadap pelaporan kewajiban perpajakan. Hal ini di tunjukkan oleh koefisien regresi X3 sebesar 0,264. Nilai signifikan variabel ketegasan sanksi perpajakan sebesar 0,009 hal ini berarti lebih kecil dari 0,05. Nilai $t_{\text {hitung }}>t_{\text {tabel }}$ atau 2,659>1,984, sehingga mengidikasikan bahwa variabel ketegasan sanksi perpajakan berpengaruh signifikan terhadap pelaporan kewajiban perpajakan. Dengan adanya ketegasan sanksi perpajakan, para pemilik UMKM akan mematuhi peraturan perpajakan yang telah ditetapkan. Hal ini disebabkan karena para pemilik UMKM menyadari peraturan dan sanksi yang akan diterima apabila tidak memenuhi kewajiban perpajakannya. Hal ini sejalan dengan teori oleh Mardiasmo dalam bukunya Perpajakan, ia mengatakan Sanksi perpajakan merupakan jaminan bahwa ketentuan peraturan perundangundangan perpajakan (norma perpajakan) akan dituruti/ditaati/dipatuhi, dengan kata lain sanksi perpajakan merupakan alat pencegah agar WP tidak melanggar norma perpajakan.

\section{Faktor yang Paling Dominan Mempengaruhi Pelaporan Kewajiban Perpajakan}

Hasil penelitian diketahui bahwa uji hipotesis menunjukkan bahwa tingkat signifikansi variabel tingkat pemahaman tingkat, tingkat kepatuhan dan ketegasan sanksi perpajakan terhadap kewajiban perpajakan adalah kurang dari 0,05 sehingga dapat disimpulkan bahwa tingkat pemahaman, tingkat kepatuhan dan ketegasan sanksi perpajakan berpengaruh secara signifikan terhadap kewajiban perpajakan.
Variabel yang paling dominan mempengaruhi pelaporan kewajiban perpajakan pemilik UMKM adalah ketegasan sanksi perpajakan karena para pengusaha UKM menyadari peraturan dan sanksi yang akan diterima apabila tidak memenuhi kewajiban perpajakannya.

\section{PENUTUP}

\section{Kesimpulan}

Berdasarkan hasil penelitian yang telah dilakukan, maka diperoleh kesimpulan sebagai berikut:

1. Pengaruh tingkat pemahaman, tingkat kepatuhan, dan ketegasan sanksi perpajakan terhadap pelaporan kewajiban perpajakan yaitu:

a. Tingkat pemahaman berpengaruh signifikan terhadap pelaporan kewajiban perpajakan pada UMKM di Kota Jambi, dikarenakan tingkat pemahaman ditunjukkan dengan nilai $t_{\text {hitung }}>t_{\text {tabel }}$ atau 2,156 > 1,984 dan nilai signifikasi 0,034 $<$ level of significant 0,05 . Dalam hal ini dapat disimpulkan bahwa pemahaman pemilik UMKM terhadap perpajakan mendorong pemilik UMKM untuk melaporkan kewajiban perpajakannya.

b. Tingkat kepatuhan berpengaruh signifikan terhadap pelaporan kewajiban perpajakan ditunjukkan dengan nilai $\mathrm{t}_{\text {hitung }}>\mathrm{t}_{\text {tabel }}$ atau 2,014 $>1,984$ dan nilai signifikan 0,047 <level of significant 0,05 . Dengan demikian, pemilik UMKM menyadari suatu ketaatan untuk melakukan ketentuan-ketentuan 
atau aturan-aturan perpajakan yang diwajibkan atau diharuskan untuk dilaksanakan.

c. Ketegasan sanksi perpajakan berpengaruh signifikan terhadap pelaporan kewajiban perpajakan ditunjukkan dengan nilai $\mathrm{t}_{\text {hitung }}>\mathrm{t}_{\text {tabel }}$ atau 2,659 > 1,984 dan nilai signifikan 0,009 $<$ level of significant 0,05 . Dengan adanya ketegasan sanksi perpajakan, para pemilik UMKM akan mematuhi peraturan perpajakan yang telah ditetapkan. Hal ini disebabkan karena para pemilik UMKM menyadari peraturan dan sanksi yang akan diterima apabila tidak memenuhi kewajiban perpajakannya.

2. Variabel yang paling dominan mempengaruhi pelaporan kewajiban perpajakan pemilik UMKM adalah ketegasan sanksi perpajakan, karena peraturan yang tegas yang akan membuat pemilik UMKM untuk patuh dan melaksanakan kewajiban perpajakannya.

\section{Saran}

Berdasarkan penelitian yang telah dilakukan maka disarankan:

1. Bagi Praktisi

Hasil penelitian ini diharapkan dapat digunakan oleh pihak terkait supaya dapat meningkatkan kesadaran dalam pelaporan kewajiban perpajakan pada pemilik UMKM dengan memperhatiakan dari segi tingkat pemahaman, tingkat kepatuhan dan ketegasan sanksi perpajakan sehingga tidak ada lagi kecurangan dalam perpajakan.
2. Bagi Akademisi

Hasil penelitian ini diharapkan dapat digunakan sebagai referensi dan dokumentasi bagi pihak kampus sebagai bahan acuan penelitian selanjutnya dalam melakukan penelitian berkaitan dengan faktor-faktor yang mempengaruhi pemilik UMKM dalam pelaporan kewajiban perpajakan, meskipun penelitian ini jauh dari kesempurnaan dan masih banyak kekurangan.

3. Bagi Peneliti Selanjutnya

Bagi peneliti selanjutnya diharapkan bisa menemukan faktor-faktor lain yang dapat memepengaruhi pemilik UMKM dalam pelaporan kewajiban perpajakan.

\section{DAFTAR KEPUSTAKAAN}

Arikunto, Suharsimi, 2006. Prosedur Penelitian Suatu Pendekatan Praktek, (Jakarta: Rineka Cipta.

Ayuningtyas, 2012. Analisis Tingkat Kesadaran Pajak pada Usaha Mikro, Kecil, dan Menengah (UMKM), Skripsi tidak diterbitkan. Jakarta: Universitas Indonesia Jakarta.

Budi, Chandra, 2013. Jutaan UMKM Pahlawan Pajak Urus Pajak Itu Sangat Mudah, Jakarta: PT. Elex Media Komputido.

Ellen Silvia Priyanti, 2013. Analisis Faktor-faktor yang Mempengaruhi Kemauan Pemilik Usaha Kecil Menengah untuk Membayar Pajak Penghasilan pada Kota Bangkinang", Riau: UIN Sultan Syarif Kasim, 2013

Hariwijaya, 2009. Pedoman Penulisan Ilmiah Proposal Dan Skripsi - Landasan Teori, Hipotesis, Analisis Statistik, Pedoman Teknik, 
Bahasa Ilmiah Pendadaran dan Yudisium, Yogyakarta: Tugu Pyblisher.

Harjanti Puspa Arum, "Pengaruh kesadaran wajib pajak, pelayanan fiskus, dan sanksi pajak terhadap kepatuhan wajib pajak orang pribadi yang melakukan kegiatan usaha", Jurnal Universitas Diponegoro.

http://www.antarajambi.com/berita/307381/ umkm-jambi-serap-30664-tenaga-kerja, , akses 26 Januari 2017.

http://www.jpnn.com/news/pajak-kota-jambihilang-rp21-m, akses 14 maret 2017.

Mardiasmo, 2011. Perpajakan Edisi Revisi 2011, Yogyakarta:Penerbit Andi.

Nasution, Rajabudin, 2015. Faktor-faktor yang Mempengaruhi Kesadaran Kewajiban Perpajakan pada Sektor Usaha Kecil dan Menengah di Kota Medan Timur", Skripsi tidak diterbitkan. Medan: Universitas Muhammadiyah Sumatera Utara.

Nenita Dewi Oroh, 2013. Analisis Faktor-faktor yang Mempengaruhi Wajib Pajak Restoran Melaporkan Kewajiban Perpajakan di Minahasa,, Jurnal Universitas Sam Batulangi Manado.

Prasetyo, Bambang, 2014. Metode Penelitian Kuantitatif, Jakarta: Rajawali Press.
Rahmatika, Mufti, 2010. Analisis Faktor-faktor yang Berpengaruh terhadap Kesadaran Kewajiban Perpajakan pada Sektor Usaha Kecil dan Menengah, Skripsi tidak diterbitkan. Jakarta: UIN Syarif Hidayatullah Jakarta.

Sukirno, Sadono, 1991. Pengantar Ekonomi Makro, Jakarta: LPFE-UI

Sunyoto, Danang, 2013. Metode Penelitian Akuntansi, Bandung: PT. Refika Aditama.

Tim Penyusun, 2010. Pedoman Penulisan Skripsi, Jambi: Syariah Press Fakultas Syariah IAIN Sulthan Thaha Saifuddin Jambi, Cet. Pertama.

Usman, Husaini, dan R. Purnomo Setiady Akbar, 2008. Pengantar Statistika, Jakarta: PT. Bumi Aksara.

Wijaya, RM. Sayid Fiska Kusuma, 2014. Faktorfaktor yang Mempengaruhi Kemauan untuk Membayar Pajak Wajib Pajak Orang Pribadi yang Melakukan Pekerjaan Bebas (Studi kasus KPP Pratama Karanganyar)", Skripsi tidak diterbitkan. Surakarta: Universitas Muhammadiyah Surakarta.

Wirapati, I Putu Waras, 2014. Faktor-faktor yang Mempengaruhi Kepatuhan Pengrajin dalam Memiliki NPWP di Kabupaten Gianyar, Bali: Universitas Udayana. 